\title{
Psychosocial model behind innovation: psychological safety, team climate and social capital
}

\author{
Dóra Klajkó ${ }^{1}$, Szilvia Kázmér-Mayer ${ }^{1}$, Szabolcs Bandi ${ }^{1}$, Gyöngyvér Csapó ${ }^{1}$ and Andrea $^{-}$ \\ Czibor $^{1}$ \\ ${ }^{1}$ University of Pécs, Hungary
}

\begin{abstract}
To stay competitive, enterprises must innovate continuously (Li \& Zheng, 2014), especially in the fast-growing industries. An innovative organizational culture is both flexible and has an internal atmosphere that can speed up information exchange and respond to new opportunities quickly (Urbancova, 2013). Enterprises need an innovation-friendly atmosphere that inspires creativity and promotes modernization (Li \& Zheng, 2014; Tsai, Horng, Liu, \& Hu, 2015). Also, they should be aware of how to build an innovative corporate culture and what factors affect a trustworthy and creative atmosphere. One of the most relevant sources of innovation is the cooperation between coworkers (Subramaniam and Youndt, 2005), through which their knowledge, expertise and ideas are accumulating to accomplish organizational goals (Edmondson and Lei, 2014). Besides cooperativity and team climate, leadership style seems to have a most critical influence on corporate innovation (Li \& Zheng, 2014; Noruzy, Dalfard, Azhdari, Nazari-Shirkouhi, \& Rezazadeh, 2013) both in private and public sectors.

Our research is aimed to examine the interrelationship between perceived leadership style and team innovation potential: workplace social capital, team climate and psychological safety.

We examined employees $(\mathrm{N}=354)$ from different Hungarian companies with an anonymous online questionnaire, measuring demographic variables, leadership-style (charismatic, ethical, transformational, authentic and transactionalist), workplace social capital (COPSOQ II, Kristensen et al., 2005; Berthelsen et al., 2016), psychological safety (Edmondson, 1999) and innovative actions of the company.

Results demonstrate a psychosocial model behind innovation. Based on our analyses, transformational and authentic leadership styles have a significant impact on the presence of
\end{abstract}


an innovation-friendly atmosphere. Psychological safety, social capital and team climate mediate the effect of leadership style on innovation.

This paper highlights the importance of internal, psychosocial organizational factors regarding an effective innovation strategy.

Keywords: leadership styles, innovation, team climate, psychological safety, social capital

\section{Introduction}

Innovation is intrinsically about identifying and using opportunities to create new products, services, or work practices (Van de Ven, 1986). As Van de Ven observed, "While the invention or conception of innovative ideas may be an individual activity, innovation (inventing and implementing new ideas) is a collective achievement" (1986: 591). Innovation is basically an effort of collaboration (Subramaniam and Youndt, 2005), complex work requires people to work together across disciplinary and other boundaries to accomplish organizational goals (Edmondson and Lei, 2014). Organizations also assimilate and integrate knowledge by facilitating communication, sharing, and transfer among individuals and by encouraging interactions in groups and networks (Allen, 1977). In this point of view, innovation has a notable "soft" and interpersonal side, so every innovation strategy should incorporate this psychosocial aspect to succeed.

\subsection{Innovative organization}

The traditional list of innovation-inducing factors includes various elements such as organizational structural dimensions, managerial attitude toward change and technical knowledge resources (Damanpour 1991). Most studies deal with the structural perspective of innovation. Lazonick and West (1998) explain how strategy and structure determine the competitive advantage of an enterprise. Mintzberg structural archetypes suggested that firms are likely to be dominated by one of the five pure archetypes, each with different innovative potential: simple structure, machine bureaucracy, professional bureaucracy, divisionalized form and adhocracy. He highlighted that bureaucratic structures are not innovative, they work well in stable environments but cannot cope with changing demands. Adhocracies are highly 
organic and flexible forms of organization and they are innovative in a volatile environment (Mintzberg, 1979). The 'structural perspectives' discussed above treats innovation as an output of certain structural, 'hard' features of the organization.

Another approach defines an innovative organization as one that is intelligent and creative (Glynn 1996; Woodman et al 1993), capable of learning effectively (Senge 1990) and creating new knowledge (Nonaka 1994; Nonaka and Takeuchi 1995). This theory argues that outputs depend on the prior accumulation of knowledge, so cognition and organizational learning in fostering innovation becomes crucially important. Viewing organizational innovation from the cognitive perspective the processes of organizational learning and knowledge creation will be given higher priority (Lam, 2008).

Zheng's study (2008) reviewed empirical studies on the relationship between social capital and innovation of the individual, team, organization, city and nation and identified the primary components of social capital-innovation relation. In this point of view innovation is the result of the interactions and exchanges of knowledge involving a diversity of actors in situations and interdependencies (Landry et al. 2002).

The common point of these aforementioned concepts is that innovation has been considered a critical dynamic capability to adapt to challenges of rapidly changing environments (Camps and Marques, 2014). To stay competitive, enterprises must renew and develop innovativity continuously ( $\mathrm{Li} \&$ Zheng, 2014), especially in fast-growing industries. (In Hungary, life sciences, vehicle, electronic, information and communication industries fall into this category (KSH, 2018).) The capacity of a company to innovate is assumed to be determined by multiple factors related to its internal (psychosocial, financial, technical, etc.) organizational conditions and the market trends (Spender and Kessler, 1995). Innovation is not just a process; they are also the result of the mindset and behavioral orientation of the company and its employees (Wang and Ahmed, 2007).

Several research aimed to explore the predictors of innovativity at organizations. In the following sections we will make an attempt to review some studies focusing on the psychosocial antecedents of innovative organizational atmosphere. 


\subsection{Predictors of organizational innovativity}

\subsubsection{Leadership style}

Leadership style is a behavioral model and trait expressed in leaders' behavior (Xie et al., 2018).Leadership style is considered to play a central role in corporate innovation ( Noruzy, Dalfard, Azhdari, Nazari-Shirkouhi, \& Rezazadeh, 2013) both in private and public sectors.

\section{Transformational leadership style}

Burns (1978) categorized leadership style into transformational and transactional leadership style. According to his theory, transformational leaders appreciate employees' ideals and values, motivates them to put organization interest in the first place, and drives them to achieve personal goals. This atmosphere helps employees achieve a higher level of demand and build an atmosphere of trust between leaders and team members. Burns described transformational leadership style along three dimensions: charismatic and inspirational leadership, intellectual stimulation, and individualized consideration.

\section{Transactional leadership style}

Transactional leadership style is a leadership model using various (mostly material) incentives to compensate the employees' efforts. (Lightwood, 1994; Longshore and Bass, 1987). This style is primarily task-oriented and helps organizations achieve their goals by making the workrelated reward and remuneration system clear (Burns, 1978). This is a

\section{Ethical leadership style}

Ethical leadership is defined as "the demonstration of normatively appropriate conduct through personal actions and interpersonal relationships, and the promotion of such conduct to followers through two- way communication, reinforcement, and decision making" (Brown et al., 2005, p. 120) The ethical leader is characterized by two primary aspects: the moral person and the moral manager. The leader holds traits such as fairness, trustworthiness, honesty, integrity, a caring nature, and exhibits ethical behavior. The leader makes decisions based upon ethical principles (Brown et al., 2005). As a moral manager, the leader promotes ethics in the organization by conveying ethical standards and values to employees, and using reward 
systems to hold employees accountable to the ethical standards (Brown et al., 2005; Brown \& Treviño, 2006). The main characteristic of ethical leadership, that distinguishes it from other styles is a "proactive influence on the ethical/unethical conduct of followers" (Brown \& Treviño, 2006, p. 600)

\section{Charismatic leadership style}

Charismatic leaders inspire team members with their own self confidence, assertiveness and communication of the purpose and goals (Avolio and Bass, 2004; Howell and Shamir, 2005). The leader increases team efficiency by inspiring a belief in the team's vision, inspiring confidence in team members' abilities. By behaviours and actions, charismatic leaders energize followers to perform toward achieving higher goals and objectives (Dvir et al., 2002; Shamir et al., 1993)

\section{Authentic leadership style}

Authentic leadership should be a root concept for any other leadership styles (Černe, Jaklič and Škerlavaj, 2013). Authenticity in leadership describes the leaders' and managers' capacity to effectively communicate information about their values, beliefs, goals, and feelings. Authentic leaders are able to adjust their leadership behaviour in accordance with their own self, their clear personal identity, and they are also able to harmonize their preferences with the demands of the society (Chan et al., 2005). An authentic leader focuses on positive achievements and promotes trust in the work team (Peterson and Luthans, 2003; Jensen and Luthans, 2006). Avolio and his colleagues defined authenticity as knowing, accepting and remaining true to one's self (Avalio, 2011).

\subsubsection{Leadership and innovation}

Existing literature have explored the effect of leadership style on innovation atmosphere (Oldham \& Cummings, 1996; Mumford, Scott, Gaddis and Strange, 2002; Tu and Lu, 2013). A study by Yoon, Lee and Schniederjans (2016) shows that leadership is the most important factor promoting the implementation of creative ideas within an organization. Leadership style at an enterprise impacts the innovation atmosphere inside it (Xie et al., 2018). 
Most of the studies examined the transformational leadership style, as a positive predictor of creative and innovative culture (Murphy and Ensher, 2008; Xie et al., 2013; Noruzy et al., 2013; Eisenbeis and Boerner, 2010). Murphy and Ensher (2008) found that the transformational leadership style enhances the confidence of members, establishes mutual trust and promotes members' cooperation and willingness for knowledge sharing. According to Xie et al. (2018), transformational leadership style is more helpful for building an innovative atmosphere, compared to transactional leadership style. In another study results showed that transformational leadership positively and indirectly influenced organizational innovation through organizational learning and knowledge management while knowledge management and organizational learning affected organizational performance indirectly through organizational innovation (Noruzy et al. 2013).

Although there are few empirical studies about the other modern leadership styles transactional leadership style ( Xie et al., 2018), ethical leadership style (Yidong and Xinxing, 2012; Shafique, Ahmad and Kalyar, 2019), charismatic leadership style (Paulsen et al., 2009; Stoker et al., 2001) and authentic leadership style (Černe, Jaklič and Škerlavaj, 2013; Müceldili, Turan and Erdil, 2013) - and its effect on innovation. Our study as a niche research aims to examine all the five modern leadership styles in one study, in relation with innovation, psychological safety and social capital.

\subsubsection{Psychological safety}

The construct of psychological safety finds its roots in early studies of organizational change. In 1965, Edgar Schein and Warren Bennis discussed psychological safety, as one of the key aspects for employees to cope with organizational challenges (Edmondson and Lei, 2014).

Reviewing the academic literature on psychological safety we can find a wide range of studies, highlighting the growing cross-sector interest in the topic since 1965. Psychological safety can be defined as a shared belief that a team is safe for taking interpersonal risks (Edmondson, 1999). The concept refers to the experience of feeling encouraged to come up with relevant ideas, questions, or concerns. Psychological safety is present when colleagues trust and respect each other, feel entitled to be honest (Edmondson, 2018) and individuals are free to focus on collective goals and problem prevention rather than on self-protection (Schein, 1993). 
Edmondson and Lei (2014) collected studies about psychological safety and they organized the concept into three streams, based on the level of analysis. At an individual level, studies conceptualize psychological safety as experiences and outcomes attributable to individuals. The most frequent outcomes are job engagement, organizational commitment, learning from failure and creative work involvement. At the second stream, psychological safety is conceptualized as an organizational-level phenomenon and measured as an average of interpersonal-climate experiences within an organization. Research in this stream identified relationships between psychological safety, social capital, high-quality relationships and firm performance. The third level conceptualizes and measures psychological safety at the group level of analysis. These studies highlight outcomes such as team learning, innovation, and performance.

Similar to the above discussion, in the case of predictors of psychological safety, some studies were focusing on the individual predictors (like status in the organizational hierarchy, Zink et al., 2008; lower level of neuroticism, Edmondson and Mogelof, 2005). Recent studies came to the conclusion that the experience of psychological safety can not be adequately explained by individual differences but it is the consequence of workplace conditions, so the responsibility of leaders for creating a psychologically safe workplace climate is undeniable (Edmondson, 2018).

Psychological safety describes a belief that undertaking individual opinions, failures, uncertainties or weaknesses will not have negative (formal or informal) consequences on the person's career or reputation at the workplace. In companies characterized by a psychologically unsafe climate, the fear from harmful consequences inhibits learning and cooperation in the organization (Edmondson, 2018). Recent studies found that ethical leadership style promotes psychological safety in groups (Walumbwa, and Schaubroeck, 2009; Brown et al., 2005).

\subsubsection{Social capital}

Organizations adopt different approaches for taking advantage and utilizing their knowledge. These approaches manifest themselves as specific aspects of intellectual capital — namely, human, organizational, and social capital (Davenport \& Prusak, 1998; Nahapiet \& Ghoshal, 1998; Schultz, 1961). An organization's capability to innovate is closely tied to its intellectual 
capital, or even more its ability to utilize its knowledge resources (Zhang, Cao and Wang, 2018).

We can describe human capital as the knowledge, skills, and abilities residing with and utilized by individuals (Schultz, 1961), whereas organizational capital is the institutionalized knowledge utilized through databases, patents, manuals, structures, systems, and processes (Youndt et al., 2004). The third aspect of intellectual capital is the social capital, defined as 'the sum of the actual and potential resources embedded within, available through, and derived from the network of relations possessed by an individual or social unit' (Nahapiet and Ghoshal 1998, p. 243).

Nahapiet and Ghoshal (1998) examined and integrated various features of social capital into three dimensions: the structural dimension, the relational dimension and the cognitive dimension. The structural dimension refers to patterns of connections between people. It is primarily impersonal and relatively objective while network density and connectivity is measurable. The relational dimension refers to the beliefs and norms that bond people together. Respect, friendship, trust, trustworthiness, expectations, norms, are key concepts in this dimension (Nahapiet and Ghoshal 1998; Coleman, 1988; Putnam, 1993; Fukuyama, 1995). The cognitive dimension refers to shared representations, interpretations and systems of meaning among people, such as shared narratives, languages and codes.

Social relations and organizational social capital are crucial for sustainable competitive advantages and innovation (Lu and Shyan, 2004; Song and Thieme, 2006; ; Eklinder- Frick, Eriksson, \& Hallén, 2014). Social capital can be one of the key resources that helps to manage the complicated and risky process of innovation (Hitt et al., 2001; Kuratko et al., 2005; Camps and Marques, 2014). Subramaniam and Youndt (2005) examined how aspects of intellectual capital influenced various innovative capabilities in organizations. They claimed that social capital is the bedrock of innovation and positively affects both incremental and radical innovative capabilities. Social capital has desirable outcomes also at the individual level (Zheng, 2008). Lin (2001) categorized these outcomes into two types: one called instrumental, such as wealth, power and reputations; and the other expressive, such as health and life satisfaction. 


\subsubsection{Team climate}

James and Sells (1981) define climate as 'individuals' cognitive representations of proximal environments, expressed in terms of psychological meaning and significance to the individual' (p. 276) Reichers and Schneider (1990) define organizational climate as '... the shared perception of the way things are around here. More precisely, climate is shared perceptions of organizational policies, practices, and procedures' (p. 22). Recent studies found the effect of dimensions of the organizational climate on the innovation behavior (Loo, 2003; Brain and Frese,2002; Weiss, Hoegl and Gibbert, 2011) Paper of Mohamad Fazali bin Ghazali; Rohaizah binti Saad (2017) provides a case study of an TCI Model as part of continuous improvement.

\section{Hypothesis}

The aim of the current study was to explore the connections between organizational psychosocial environment and perceived organizational innovativity; to discover a psychosocial model behind innovation. (Figure 1)

Figures 1: Theoretical framework of psychosocial model behind innovation

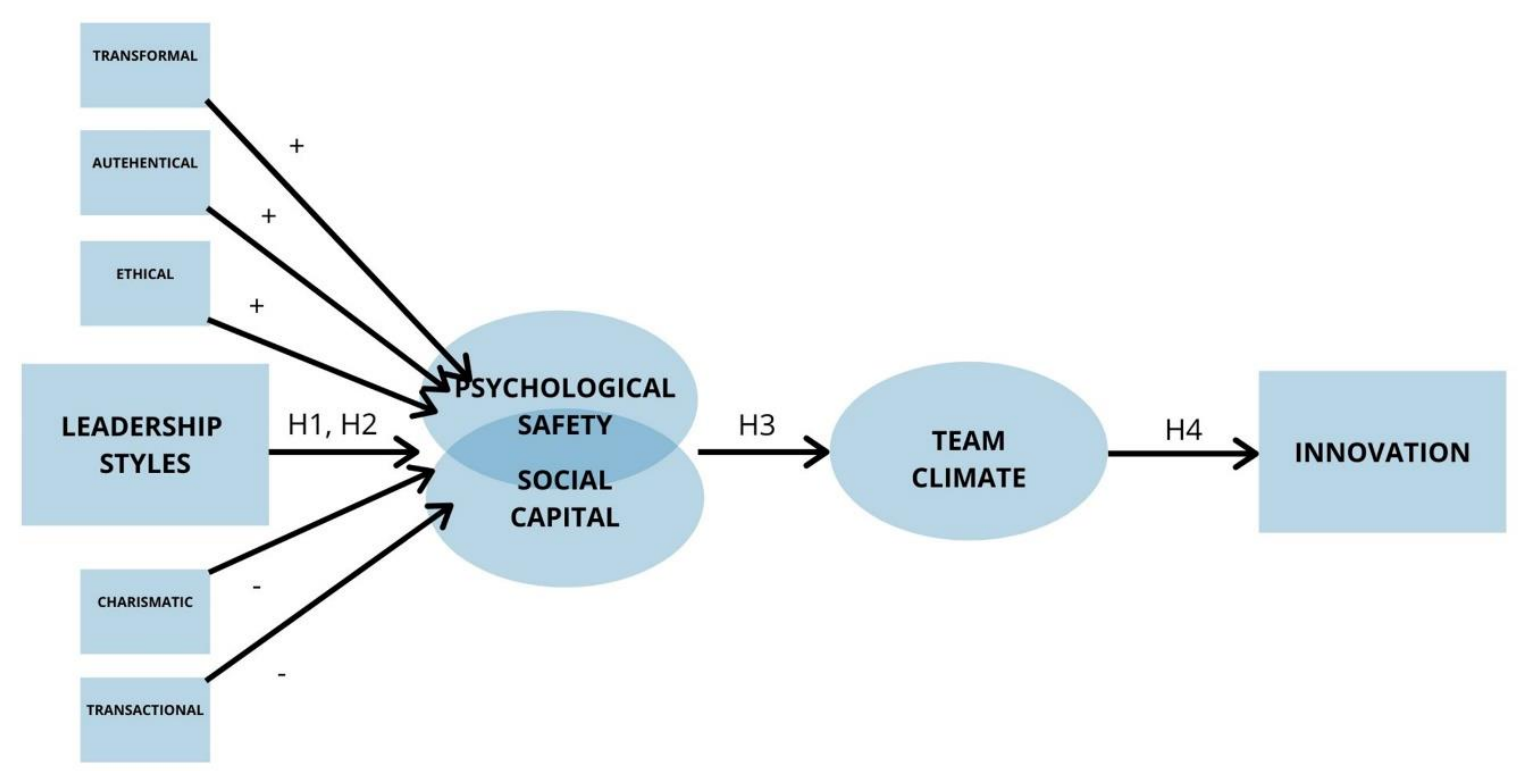

Source: Edited by Dóra Klajkó 


\section{Methods}

We examined the effect of different types of leadership style and organizational cultures on workplace social capital and psychological safety, which are important internal organizational factors regarding innovation.

\subsection{Sample}

A total of 354 employees from Hungarian companies participated in the study. Criteria for inclusion in the sample were eighteen years of age and at least one year of active employment with minimum 4 hours a week. Of the overall sample, $37 \%(n=128)$ were males and $63 \%$ $(n=225)$ were females. Participants' age ranged from 18 to 67 years $(M=38,89)$. Tertiary education was completed by $58.1 \%$, secondary education by $39.4 \%$ and primary education by $0,8 \%$ ( $1,7 \%$ of participants marked the other category). According to the position, $76,5 \%$ of the fillers are employees, $17,8 \%$ are working in the middle management and 5,7\% are top managers. Distribution of most represented sectors involved in the research was: $17 \%$ of production; $14,4 \%$ of HR marketing and PR; $9,1 \%$ of IT; $9,1 \%$ of tourism and gastronomy.

\subsection{Instruments}

Participants completed an online questionnaire-package anonymously. They provided demographic data first: age, gender, occupational area and position at the company. Then they completed a self-constructed questionnaire about modern leadership styles, Organizational Culture Assessment Instrument (OCAI; Cameron \& Quinn, 2002), the short version of Psychological Safety Questionnaire (Edmondson, 1999) and the workplace social capital scales of Copenhagen Psychosocial Questionnaire (Kristensen et al., 2005; Pejtersen et al., 2010). The last part of the instrument included questions about the number of innovative practices and perceived success of the company.

\subsubsection{Leadership styles}

A new instrument was created to measure the perceived style of leadership. The items of the questionnaire were representing five different modern leadership style: transformative leadership (9 items, e.g. "Involves employees in the creation of a motivating organizational vision."), transactional leadership (9 items, e.g. "Rewards extra efforts mainly by financial means."), ethical leadership (9 items, e.g. "Motivates employees to consider moral values at 
work." ), charismatic leadership (8 items, e.g. "Has a charming, appealing personality.") and authentic leadership (9 items, e.g. "Makes decisions based on personal beliefs and values."). In responding to the questionnaire, subjects report the extent to which they agree or disagree regarding how each item applies to their leader by rating them on a 7-point Likert scale.

\subsubsection{Social capital}

The Copenhagen Psychosocial Questionnaire (COPSOQ II) developed by the Danish National Research Centre is a valid instrument for the assessment of psychosocial work environment (Kristensen et al., 2005; Pejtersen et al., 2010). The COPSOQ II questionnaire reflects a broad perspective on both positive and negative aspects of the psychosocial work environment such as demands at work, work organization and job-contents, interpersonal relations and leadership, work-family conflict, health, well-being, and offensive behaviours as well as social capital at workplace level (Pejtersen et al., 2010).

Interpersonal relationships characterized by mutual trust and justice are considered fundamental pillars of workplace social capital (Healy and Côté, 2001; Kawachi et al., 2013; Olesen et al., 2008). In line with this theoretical approach, COPSOQ II includes scales for mutual trust between employees (e.g. "Do employees withhold information from one another?”), trust regarding management ((e.g. "Do managers trust that employees are doing their job well?”) and justice (e.g. “Do managers take all colleagues' suggestions seriously?”).

\subsubsection{Psychological safety}

Team psychological safety, defined as the extent to which the team views the social climate as conducive to interpersonal risk. We measured team psychological safety level with the help of a 7 item questionnaire by Amy C. Edmondson (1999) with a seven-point Likert scale (e.g. "It is safe to take a risk in this team.")

\subsubsection{Team Climate}

The Team Climate Inventory (TCI) was developed by Anderson and West (1998) to measure team functions. The questionnaire assesses four climate factors predictive of innovation: vision (e.g. "How clear are you about what your team's objective are?”), participative safety (e.g. "We share information generally in the team rather than keeping it to ourselves."), task orientation (e.g. "Disagreeing with another's idea is not a rejection of that person"), support 
for innovation (e.g. "This team is open and responsive to change.") We used the modified, short 14-item tool with a five-point Likert scale.

\subsubsection{Organizational innovation activities}

Our intention was to measure the intensity of the company's structural and behavioural innovation activity. We collected 18 various innovation activities (e.g. "We have created a unique product / software / technical solution / tool / methodology and others use it effectively”) along the study of Lendel, Moravčíková and Latka (2017). Participants rated the different activities regarding how often (never, sometimes, constantly) they experience them at their workplace.

\subsection{Statistics}

Our research aimed to explore a psychosocial model behind innovation. In order to test the relationship between the different variables, structural equation modelling was conducted using JASP 0.11.0 and IBM SPSS Statistics 25.

\subsection{Results}

\subsubsection{Psychosocial model behind innovation}

To answer our research questions, and explored a complex psychosocial model behind innovation. Data were analysed according to the steps recommended for multi-sample structural equation modeling (SEM) by Byrne (2010). SEM is a statistical methodology where the researcher defines a theoretical model of relations between the variables. It allows using two or more observed variables as indicators of an unobserved underlying construct termed a latent variable. The theoretical or hypothesized model can be tested statistically to determine the extent to which it is consistent with the data or how well it fits the data. The hypothesized model was tested using the maximum likelihood method. The $\chi^{2}$ statistic (CMIN; degrees of freedom $[\mathrm{df}]=10, \mathrm{n}=354$ ) was 11.363, $\mathrm{p}=0.330$; it confirms the model. (Figure 2.; Table1.) The goodness of fit index $(\mathrm{GFI}=0.986)$, the comparative fit index $(\mathrm{CFI}=0.997)$ and the root mean square error of approximation index $($ RMSEA $=0.020)$ showed a good fit, as they were above 0.90 (Byrne, 2001). (Figure 2.; Table 2.) 
Figure 2: Path diagram of SEM analysis. Effect of leadership styles, psychological safety, social capital and team climate on innovation

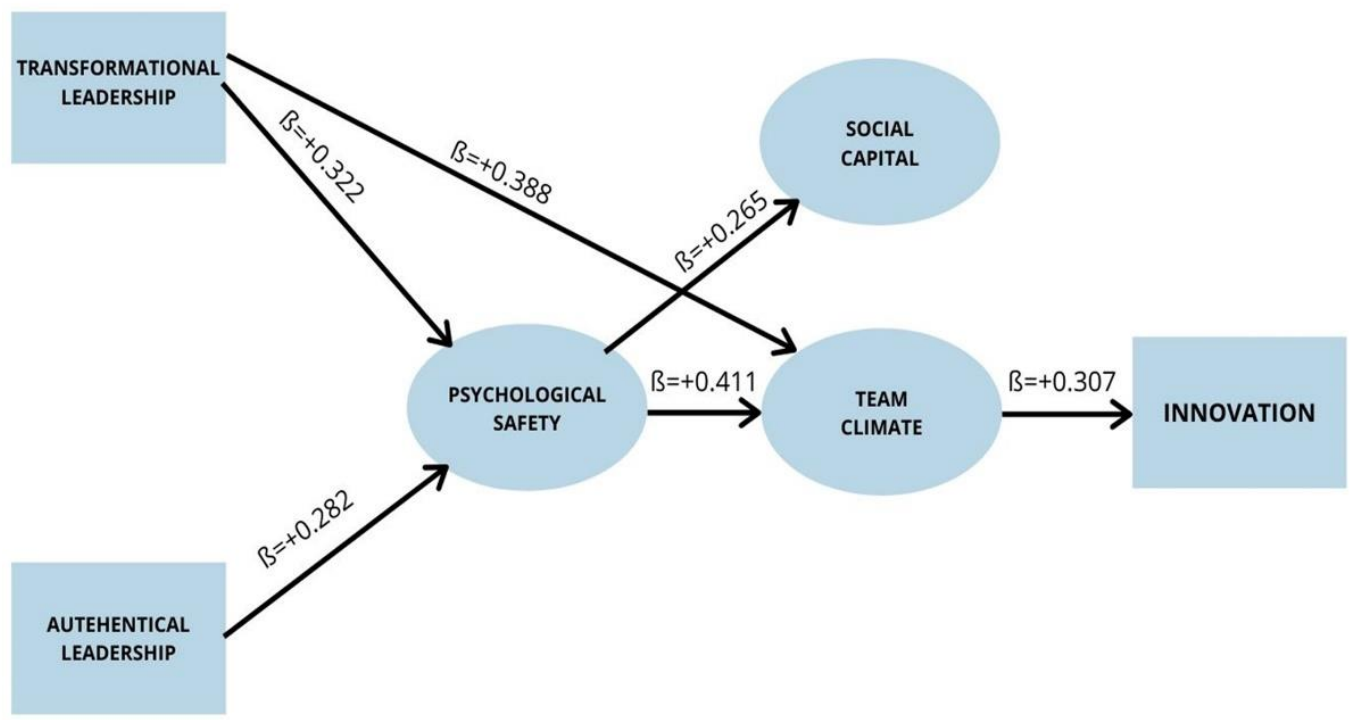

$X 2(10)=11.363 ; p=0,330 ; C M I N / D F=1.136 ; C F I=.997 ; T L I=.993 ; N F I=.976 ; R M S E A=.020 ; S R M R=.025 ; G F I=0.986 ;$ $a G F I=950 ; M F I=.998 ; A I C=5158.380 ; B I C=5220.243$

Study highlights results under $0.001 \mathrm{p}$-values in the model. Regression weights revealed impact of different leadership styles on organizational psychological safety with transformational $(b=0.32)$, and authentical $(b=0.29)$ leadership style having the highest impact. Regression weights revealed the effect of organizational psychological safety on innovative team climate $(b=0.41)$, which has an impact on organizational innovative activities $(b=0.30)$. Transformational leadership $(b=0.14)$ and psychological safety $(b=0.27)$ showed a significant impact on workplace social capital. (Figure 2., Table 3.) These psychosocial aspects together could predict innovation activity at $30 \%$.

\section{Discussion}

This study aimed to test a model that describes the psychosocial antecedents of innovation among Hungarian employees $(\mathrm{n}=354)$. 
One of the notable results of this study is that two types of perceived leadership style have a significant positive impact on organizational innovation activity: transformational and authentic leadership. The model supports previous studies about the relationship of transformational and authentic leadership styles and innovation ( Xie et al., 2013; Noruzy et al., 2013; Eisenbeis and Boerner, 2010; Černe, Jaklič and Škerlavaj, 2013). Murphy and Ensher (2008) found that the transformational leadership style establishes mutual trust and promotes members' cooperation and willingness for knowledge sharing. While, according to the study of Müceldini, Turan and Erdil (2013) authentic leadership is correlated with creativity and innovativity.

Appreciating employees' ideals and values and motivating them to put organization interest in the first place are vital to build an innovative culture. Transformational leadership helps employees achieve a higher level of demand and build an atmosphere of trust between leaders and team members. The concept of authentic leadership style supports managers to communicate vision clearly and motivate employees with strong personal identity.

Our results show that transformational and authentic leadership exert their effect on perceived innovativity through psychological safety and team climate. Leaders with transformational or authentic style can be able to build an organizational culture, value system, where a psychologically safe working environment combined with clear visions, participative safety, task orientation and a supportive atmosphere helps to ground organizational innovativity.

These results draw up some ideas that can be used in organizational development programs aimed to increase or maintain organizational innovativity. Based on these findings, OD programs should focus on two psychological aspects: leadership and team-atmosphere. While empowering leaders with transformational and authentic leadership tools and mentality, and helping them be aware of group dynamics and organizational practices responsible for a psychologically safe and innovation friendly group climate can lead to an increased level of innovation at work.

Although we think that these results contribute to the understanding of the psychological roots of organizational innovativity, some limitations of the study should be noted. First, the sample of this study was not representative for Hungarian employees, highly educated women respondents were overrepresented in our sample. Secondly, we used self-reported measures, and did not control for social desirability effects. Nonetheless, the anonymity of the testing 
situations and the online testing methodology may have decreased the effect of socially desirable responding. And thirdly, we used two, not-yet validated measurements in this study, the measures of innovative organizational actions and perceived leadership styles were developed for this research, based on previous theoretical models.

In conclusion, the results highlight the crucial effect of soft and interpersonal workplace factors on innovation. Psychological variables, like perceived leadership style, psychological safety and team climate have a remarkable predictive, explanatory power for the innovative potential of a company. Organizational development programs should not neglect these aspects: a complex innovation strategy should contain several boosters to achieve organizational goals.

\section{Acknowledgment}

The research was financed by the Higher Education Institutional Excellence Programme of the Ministry of Human Capacities in Hungary, within the framework of the 4th thematic program "Enhancing the Role of Domestic Companies in the Reindustrialization of Hungary" of the University of Pécs (reference number of the contract: 20765-3/2018/FEKUTSTRAT).

\section{References}

Anderson, N. R., and West, M. A. (1998). Measuring climate for work group innovation: Development and validation of the Team Climate Inventory. Journal of Organizational Behavior, 19(3), 235--258.

Allen, T. (1977). Managing the flow of technology: Technology transfer and the dissemination of technological information within the $\mathrm{R} \& \mathrm{D}$ organization. Cambridge, MA: MIT Press

Avolio, B.J. and Bass, B.M. (2004). Multifactor Leadership Questionnaire: Third Edition and Sampler Set. Mind Garden Inc: Redwood City

Baer, M. and Frese, M. (2002). Innovation is not enough: climates for initiative and psychological safety, process innovations, and firm performance. Journal of Organizational Behavior, 24(1), 45-68. doi:10.1002/job.179 
Bain, P. G., Mann, L., \& Pirola-Merlo, A. (2001). The Innovation Imperative. Small Group Research, 32(1), 55-73. doi:10.1177/104649640103200103

Byrne, B. M. (2010). Structural equation modeling with AMOS: Basic concepts, applications, and programming. 2nd Edition. Routledge Taylor \& Francis Group.

Brown, M. E., and Treviño, L. K. (2006). Ethical leadership: A review and future directions. The Leadership Quarterly, 17, 595-616

Brown, M. E., Treviño, L. K., and Harrison, D. A. (2005). Ethical leadership: A social learning perspective for construct development and testing. Organizational Behavior and Human Decision Processes, 97, 117-134.

Brown, M. E., Treviño, L. K., and Harrison, D. A. (2005). Ethical leadership: A social learning perspective for construct development and testing. Organizational Behavior and Human Decision Processes, 97, 117-134.

Burns, J.M.(1978). Leadership. NY.

Camps, S., \& Marques, P. (2014). Exploring how social capital facilitates innovation: The role of innovation enablers. Technological Forecasting and Social Change, 88, 325-348. doi:10.1016/j.techfore.2013.10.008

Černe, M., Jaklič, M., and Škerlavaj, M. (2013). Authentic leadership, creativity, and innovation: A multilevel perspective. Leadership, 9(1), 63-85. doi:10.1177/1742715012455130

Chan A.,W.L., Hannah, S.T. and Gardner, W.L. (2005). Veritable authentic leadership: Emergence, functioning, and impact. In: Gardner, W.L., Avolio, B.J. and Walumbwa, F.O. (eds) Authentic Leadership Theory and Practice: Origins, Effects and Development. Oxford: Elsevier, pp. 3-41

Chatman, J. A., and Eunyoung Cha, S. (2003). Leading by leveraging culture. California Management Review, 45, 19-34 
Davenport, T. H., and Prusak, L. (1998). Working knowledge: How organizations manage what they know. Boston: Harvard Business School Press

Dvir, T., Eden, D., Avolio B. and Shamir, B. (2002). Impact of transformational leadership on follower development and performance: a field experiment. Academy of Management Review, Vol. 45, No. 4, pp. 735-744.

Edmondson, A. (1999). Psychological Safety and Learning Behavior in Work Teams. Administrative Science Quarterly, 44(2), 350. doi:10.2307/2666999

Edmondson, A. C. (Ed.).(2018). The Fearless Organization: Creating Psychological Safety in the Workplace for Learning, Innovation, and Growth. Hoboken, NJ: John Wiley \& Sons

Edmondson, A. C. and Lei, Z. (2014). Psychological Safety: The History, Renaissance, and Future of an Interpersonal Construct. Annual Review of Organizational Psychology and Organizational Behavior, 1(1), 23-43. doi:10.1146/annurev-orgpsych-031413091305

Edmondson, A.C., Mogelof, J.P. (2005). Explaining psychological safety in innovation teams. In Creativity and Innovation in Organizations, ed. L Thompson, H Choi, pp. 10936. Mahwah, NJ: Erlbaum

Eisenbeiß, S. A., and Boerner, S. (2010). Transformational Leadership and R\&D Innovation: Taking a Curvilinear Approach. Creativity and Innovation Management, 19(4), 364-372. doi:10.1111/j.1467-8691.2010.00563.x

Eklinder- Frick, J., Eriksson, L., and Hallén, L. (2014). Multidimensional social capital as a boost or a bar to innovativeness. Industrial Marketing Management, 43, 460-472

Glynn, M. A. (1996). Innovative Genius: A framework for relating Individual and Organizational Intelligence to Innovation. Academy of Management Review, 21/4:10811111 
Granovetter, M.S. (1983). The strength of weak ties: a network theory revisited. Sociological Theory, 1, pp. 201-233.

Howell, J.M. and Shamir, B. (2005). The role of followers in the charismatic leadership process: relationships and their consequences. The Academy of Management Review, Vol. 30, No. 1, pp. 96-112.

Jensen, S., and Luthans, F. (2006). Entrepreneurs as authentic leaders: Impact on employees' attitudes. Leadership \& Organization Development Journal 27(8): 646-666.

King, N. (1990). Innovation at work: The research literature. In M. A. West \& J. L. Farr (Eds.), Innovation and creativity at work: Psychological and organizational strategies (p. 15-59). John Wiley \& Sons.

Kivimaki, M., Lansisalmi, H., Elovainio, M., Heikkila, A., Lindstrom, K., Harisalo, R., Puolimatka, L. (2000). Communication as a determinant of organizational innovation. $R$ and D Management, 30(1), 33-42. doi:10.1111/1467-9310.00155

Landry, R., Amara, N. and Lamari, M. (2002). Does social capital determine innovation? Technological Forecasting and Social Change, 69, pp. 681-701.

Leithwood, K.(1994). Leadership for school restructuring. Educ. Adm. Q. 30 (4), 498518.

Lendel, V., Moravčíková, D., and Latka, M. (2017). Organizing Innovation Activities in Company. Procedia Engineering, 192, 615-620. doi:10.1016/j.proeng.2017.06.106

Lin, N. (2001). Social Capital: A Theory of Social Structure and Action. Cambridge, MA: Cambridge University Press.

Loo, R. (2003). Assessing "team climate" in project teams. International Journal of Project Management, 21(7), 511-517. doi:10.1016/s0263-7863(02)00058-3 
Longshore, J. M. and Bass, B. M. (1987). Leadership and Performance beyond Expectations. The Academy of Management Review, 12(4), 756. doi:10.2307/258081

Lu,L.Y. and Shyan, Y. (2006) The R\&D and marketing cooperation across new product development stages: an empirical study of Taiwan's IT industry. Ind. Mark. Manag. 33 (2004) 593-605.

Mintzberg, H. (1979). The Structuring of Organization. Englewood Cliffs, N.J.: Prentice Hall.

Müceldili, B., Turan, H., and Erdil, O. (2013). The Influence of Authentic Leadership on Creativity and Innovativeness. Procedia. Social and Behavioral Sciences, 99, 673-681. doi:10.1016/j.sbspro.2013.10.538

Mumford, M. D. (2000). Managing creative people: Strategy and tactics for innovation. Human Resource Management Review, 10, 313-351

Murphy, S.E. and Ensher, E.A. (2008). A qualitative analysis of charismatic leadership in creative teams: the case of television directors. Leadersh. Q. 19 (3), 335-352.

Nahapiet, J. and Ghoshal, S. (1998). Social capital, intellectual capital, and the organizational advantage. Academy of Management Review, 23: 242-266.

Nahapiet,J. and Ghoshal S. (1998). Social capital, intellectual capital, and the organizational advantage. Acad. Manag. Rev. 23, 242-266.

Noruzy, A., Dalfard, V.M., Azhdari, B. et al. (2013). Relations between transformational leadership, organizational learning, knowledge management, organizational innovation, and organizational performance: an empirical investigation of manufacturing firms. Int $J$ Adv Manuf Technol 64, 1073-1085. https://doi.org/10.1007/s00170-012-4038-y

Oldham, G. R., and Cummings, A. (1996). Employee creativity: Personal and contextual factors at work. Academy of Management Journal, 39, 607-655. 
Pasricha, P., and Rao, M. K. (2018). The effect of ethical leadership on employee social innovation tendency in social enterprises: Mediating role of perceived social capital. Creativity and Innovation Management, 27(3), 270-280. doi:10.1111/caim.12287

Paulsen, N., Maldonado, D., Callan, V. J., and Ayoko, O. (2009). Charismatic leadership, change and innovation in an R\&D organization. Journal of Organizational Change Management, 22(5), 511-523. doi:Doi 10.1108/09534810910983479

Peterson, S., and Luthans, F. (2003). The positive impact and development of hopeful leaders. Leadership \& Organization Development Journal 24(1): 26-31.

Schultz, T. W. (1961). Investment in human capital. American Economic Review, 51: 117.

Senge, P. (1990). The Fifth Discipline: the Art and Practice of the Learning Organization. New York: Doubleday

Shafique, I., Ahmad, B. and Kalyar, M. (2019). How ethical leadership influences creativity and organizational innovation: Examining the underlying mechanisms. European Journal of Innovation Management, Vol. 23 No. 1, pp. 114-133. https://doi.org/10.1108/EJIM-12-2018-0269

Shamir, B., House, R.J. and Arthur, M.B. (1993). The motivational effects of charismatic leadership: a self-concept based theory. Organization Science, Viol. 4, No. 4, pp.577-594.

Song, X.M. and Thieme, R. (2006). A cross-national investigation of the R\&D marketing interface in the product innovation process, Ind. Mark. Manag. 35, 308-322.

Souder, W. E., and Sherman, J. D. (Eds.). (1994). Managing new technology development. New York: McGraw-Hill. 
Spender, J. C. and Kessler, E. H. (1995). Managing the Uncertainties of Innovation: Extending Thompson (1967). Human Relations, 48(1), 3556.https://doi.org/10.1177/001872679504800103

Stocker, J.I., Looise, J.C., Fissher, O.A.M. and de Jong, R. D. (2001). Leadership and innovation: relations between leadership, individual characteristics and the functioning of R\&D teams. International Journal of Human Resource Management, Vol. 12, No. 7, 1 pp.141-1151.

Subramaniam,M. and Youndt, M.A. (2005). Influence of intellectual capital on the types of innovative capabilities, Acad. Manag. J. 48. 450-463.

Van de Ven, A. H. (1986). Central problems in the management of innovation. Management Science, 32: 590-607.

Walumbwa, F. O., and Schaubroeck, J. (2009). Leader personality traits and employee voice behavior: Mediating roles of ethical leadership and work group psychological safety. Journal of Applied Psychology, 94(5), 1275-1286. doi:10.1037/a0015848

Wang,C.L. and Ahmed, P.K. (2004). The development and validation of the organizational innovativeness construct using confirmatory factor analysis. Eur. J. Innov. Manag. 7 (4) 303-313.

Weiss, M., Hoegl, M., \& Gibbert, M. (2011). Making Virtue of Necessity: The Role of Team Climate for Innovation in Resource-Constrained Innovation Projects. Journal of Product Innovation Management, 28(s1), 196-207. doi:10.1111/j.15405885.2011.00870.x

Woodman, R.W., Sawyer, J., Griffin, R.. (1993). Toward a Theory of Organizational Creativity. Academy of Management Review, 18. 293-321. 10.5465/AMR.1993.3997517. 
Xie, Y., Xue, W., Li, L., Wang, A., Chen, Y., Zheng, Q., Li, X. (2018). Leadership style and innovation atmosphere in enterprises: An empirical study. Technological Forecasting and Social Change. doi:10.1016/j.techfore.2018.05.017

Yoon, S.N., Lee, D., Schniederjans, M. (2016). Effects of innovation leadership and supply chain innovation on supply chain efficiency: focusing on hospital size. Technol. Forecast. Soc. Chang. 113, 412-421.

Yu, T. and Wu, N. (2009). A Review of Study on the Competing Values Framework. International Journal of Business and Management, 4(7). doi:10.5539/ijbm.v4n7p37

Zhang, L., Cao, T., and Wang, Y. (2018). The mediation role of leadership styles in integrated project collaboration: An emotional intelligence perspective. International Journal of Project Management, 36(2), 317-330. doi:10.1016/j.ijproman.2017.08.014

Zheng, W. (2008). A Social Capital Perspective of Innovation from Individuals to Nations: Where is Empirical Literature Directing Us? International Journal of Management Reviews, 12(2), 151-183. doi:10.1111/j.1468-2370.2008.00247.x

Zink, C.F., Tong, Y., Chen, Q., Bassett, D.S., Stein, J.L., and Meyer-Lindenberg, A. (2008). Know Your Place: Neural Processing of Social Hierarchy in Humans. Neuron 58.2 (2008): $273-83$. 


\section{Tables}

Table 1: SEM analysis of psychosocial model behind innovation with JASP. The effect of leadership styles (transformational and authentical), psychological safety, social capital and team climate on organizational innovative activities.

\begin{tabular}{|l|l|l|l|l|l|l|l|l|l|l|l|l|}
\hline $\begin{array}{l}\text { Chi } \\
\text { Square } \\
\text { Test } \\
\text { Statistic } \\
\text { (unscaled) }\end{array}$ & & & & & & & & & & & & \\
\hline & & df & & AIC & & BIC & & $\chi^{2}$ & & $\Delta \boldsymbol{\chi}^{2}$ & & p \\
\hline Saturated & 0 & & $\cdot$ & & $\cdot$ & & 0 & & $\cdot$ & & $\cdot$ \\
\hline Model 1 & & 10 & & 5166.38 & & 5243.709 & & 11.363 & & 11.363 & & $\mathbf{0 . 3 3}$ \\
\hline
\end{tabular}

Table 2: Model fit indexes of SEM analysis with JASP. The effect of leadership styles (transformational and authentical), psychological safety, social capital and team climate on organizational innovative activities.

\begin{tabular}{|l|l|}
\hline & Model \\
\hline $\begin{array}{l}\text { Minimum Function Test } \\
\text { Statistic }\end{array}$ & 0.016 \\
\hline$\chi^{\mathbf{2}}$ & \\
\hline Degrees of freedom & 11.363 \\
\hline p & 10 \\
\hline & \\
\hline $\begin{array}{l}\text { User model versus } \\
\text { baseline model }\end{array}$ & 0.33 \\
\hline & \\
\hline $\begin{array}{l}\text { Comparative Fit Index } \\
\text { (CFI) }\end{array}$ & 0.997 \\
\hline Tucker-Lewis Index (TLI) & 0.993 \\
& \\
\hline
\end{tabular}




\begin{tabular}{|l|l|}
\hline $\begin{array}{l}\text { Bentler-Bonett Non- } \\
\text { normed Fit Index (NNFI) }\end{array}$ & 0.993 \\
\hline $\begin{array}{l}\text { Bentler-Bonett Normed } \\
\text { Fit Index (NFI) }\end{array}$ & 0.976 \\
\hline $\begin{array}{l}\text { Parsimony Normed Fit } \\
\text { Index (PNFI) }\end{array}$ & 0.444 \\
\hline $\begin{array}{l}\text { Bollen's Relative Fit Index } \\
\text { RFI) }\end{array}$ & 0.947 \\
\hline $\begin{array}{l}\text { Loglikelihood user model } \\
\text { (Ho) }\end{array}$ & \\
\hline $\begin{array}{l}\text { Bollen's Incremental Fit } \\
\text { Index (RNI) }\end{array}$ & 0.997 \\
\hline
\end{tabular}




\begin{tabular}{|c|c|}
\hline $\begin{array}{l}\text { Loglikelihood unrestricted } \\
\text { model (H1) }\end{array}$ & -2557.51 \\
\hline $\begin{array}{l}\text { Number of free } \\
\text { parameters }\end{array}$ & 20 \\
\hline Akaike (AIC) & 5166.38 \\
\hline Bayesian (BIC) & 5243.709 \\
\hline $\begin{array}{l}\text { Sample-size adjusted } \\
\text { Bayesian (BIC) }\end{array}$ & 5180.261 \\
\hline \multirow[t]{2}{*}{$\begin{array}{l}\text { Root Mean Square Error } \\
\text { of Approximation }\end{array}$} & \\
\hline & Model \\
\hline RMSEA & 0.02 \\
\hline $\begin{array}{l}90 \text { Percent Confidence } \\
\text { Interval }\end{array}$ & $\begin{array}{l}0.000- \\
0.063\end{array}$ \\
\hline p-value RMSEA <= 0.05 & 0.848 \\
\hline \multirow[t]{2}{*}{$\begin{array}{l}\text { Standardized Root Mean } \\
\text { Square Residual }\end{array}$} & \\
\hline & Model \\
\hline RMR & 0.259 \\
\hline RMR (No Mean) & 0.286 \\
\hline SRMR & 0.023 \\
\hline \multirow[t]{2}{*}{ Other Fit Indices } & \\
\hline & Model \\
\hline
\end{tabular}




\begin{tabular}{|c|c|}
\hline $\begin{array}{l}\text { Hoelter Critical N (CN) } \\
\text { alpha=0.05 }\end{array}$ & 569.732 \\
\hline $\begin{array}{l}\text { Hoelter Critical N (CN) } \\
\text { alpha=0.01 }\end{array}$ & 722.025 \\
\hline $\begin{array}{l}\text { Goodness of Fit Index } \\
\text { (GFI) }\end{array}$ & 0.999 \\
\hline $\begin{array}{l}\text { Parsimony Goodness of } \\
\text { Fit Index (GFI) }\end{array}$ & 0.998 \\
\hline $\begin{array}{l}\text { McDonald Fit Index } \\
\text { (MFI) }\end{array}$ & 0.998 \\
\hline $\begin{array}{l}\text { Expected Cross- } \\
\text { Validation Index (ECVI) }\end{array}$ & 0.146 \\
\hline R-Squared & \\
\hline Variable & $\mathbf{R}^{2}$ \\
\hline PSZICHBIZT & 0.317 \\
\hline COPSOQ_TARSAS_TOKE & 0.131 \\
\hline TCI & 0.485 \\
\hline INNOVACIO & 0.107 \\
\hline
\end{tabular}


$2^{\text {nd }}$ International Conference on

SOCIAL SCIENCES IN THE 21ST CENTURY

Table 3: Parameter estimates of SEM analysis with JASP. The effect of leadership styles (transformational and authentical), psychological safety, social capital and team climate on organizational innovative activities.

\begin{tabular}{|c|c|c|c|c|c|c|c|c|}
\hline $\begin{array}{l}\text { Parameter } \\
\text { Estimates }\end{array}$ & & & & & & & & \\
\hline & & & $\begin{array}{l}\text { lab } \\
\text { el }\end{array}$ & est & se & $\mathbf{z}$ & $\mathbf{p}$ & $\begin{array}{l}\text { CI } \\
\text { (low } \\
\text { er) }\end{array}$ \\
\hline PSZICHBIZT & $\sim$ & $\begin{array}{l}\text { VEZ_TRA } \\
\text { NSZ }\end{array}$ & & $\begin{array}{l}0.2 \\
62\end{array}$ & $\begin{array}{l}0.0 \\
71\end{array}$ & $\begin{array}{l}3.6 \\
78\end{array}$ & $\begin{array}{l}<.0 \\
01\end{array}$ & $\begin{array}{l}0.12 \\
3\end{array}$ \\
\hline PSZICHBIZT & $\sim$ & VEZ_AUT & & $\begin{array}{l}0.2 \\
9\end{array}$ & $\begin{array}{l}0.0 \\
92\end{array}$ & $\begin{array}{l}3.1 \\
64\end{array}$ & $\begin{array}{l}0.00 \\
2\end{array}$ & 0.11 \\
\hline PSZICHBIZT & $\sim$ & $\begin{array}{l}\text { VEZ_TRA } \\
\text { NZ }\end{array}$ & & $\begin{array}{l}- \\
0.1 \\
59 \\
\end{array}$ & $\begin{array}{l}0.0 \\
68\end{array}$ & $\begin{array}{l}- \\
2.3 \\
57 \\
\end{array}$ & $\begin{array}{l}0.01 \\
8\end{array}$ & $\begin{array}{l}- \\
0.29 \\
2 \\
\end{array}$ \\
\hline PSZICHBIZT & $\sim$ & $\begin{array}{l}\text { VEZ_KAR } \\
\text { IZM }\end{array}$ & & $\begin{array}{l}- \\
0.1 \\
84\end{array}$ & $\begin{array}{l}0.0 \\
83\end{array}$ & $\begin{array}{l}- \\
2.2 \\
3\end{array}$ & $\begin{array}{l}0.02 \\
6\end{array}$ & $\begin{array}{l}- \\
0.34 \\
6\end{array}$ \\
\hline $\begin{array}{l}\text { COPSOQ_TARSAS } \\
\text { _TOKE }\end{array}$ & $\sim$ & $\begin{array}{l}\text { PSZICHBI } \\
\text { ZT }\end{array}$ & & $\begin{array}{l}0.2 \\
41\end{array}$ & $\begin{array}{l}0.0 \\
53\end{array}$ & $\begin{array}{l}4.5 \\
38\end{array}$ & $\begin{array}{l}<.0 \\
01\end{array}$ & $\begin{array}{l}0.13 \\
7\end{array}$ \\
\hline $\begin{array}{l}\text { COPSOQ_TARSAS } \\
\text { _TOKE }\end{array}$ & $\sim$ & $\begin{array}{l}\text { VEZ_TRA } \\
\text { NSZ }\end{array}$ & & $\begin{array}{l}0.1 \\
06\end{array}$ & $\begin{array}{l}0.0 \\
43\end{array}$ & $\begin{array}{l}2.4 \\
62\end{array}$ & $\begin{array}{l}0.01 \\
4\end{array}$ & $\begin{array}{l}0.02 \\
2\end{array}$ \\
\hline TCI & $\sim$ & $\begin{array}{l}\text { PSZICHBI } \\
\text { ZT }\end{array}$ & & $\begin{array}{l}0.2 \\
65\end{array}$ & $\begin{array}{l}0.0 \\
29\end{array}$ & $\begin{array}{l}9.0 \\
47\end{array}$ & $\begin{array}{l}<.0 \\
01\end{array}$ & $\begin{array}{l}0.20 \\
8\end{array}$ \\
\hline TCI & $\sim$ & $\begin{array}{l}\text { VEZ_TRA } \\
\text { NSZ }\end{array}$ & & $\begin{array}{l}0.2 \\
04\end{array}$ & $\begin{array}{l}0.0 \\
24\end{array}$ & $\begin{array}{l}8.6 \\
27\end{array}$ & $\begin{array}{l}<.0 \\
01\end{array}$ & $\begin{array}{l}0.15 \\
8\end{array}$ \\
\hline TCI & $\sim$ & $\begin{array}{l}\text { VEZ_TRA } \\
\text { NZ }\end{array}$ & & $\begin{array}{l}0.1 \\
09\end{array}$ & $\begin{array}{l}0.0 \\
34\end{array}$ & $\begin{array}{l}3.2 \\
11\end{array}$ & $\begin{array}{l}0.00 \\
1\end{array}$ & $\begin{array}{l}0.04 \\
2\end{array}$ \\
\hline INNOVACIO & $\sim$ & TCI & & $\begin{array}{l}4.7 \\
86\end{array}$ & $\begin{array}{l}0.7 \\
84\end{array}$ & $\begin{array}{l}6.1 \\
03\end{array}$ & $\begin{array}{l}<.0 \\
01\end{array}$ & $\begin{array}{l}3.24 \\
9\end{array}$ \\
\hline INNOVACIO & $\sim$ & $\begin{array}{l}\text { VEZ_TRA } \\
\text { NZ }\end{array}$ & & $\begin{array}{l}- \\
1.7 \\
78\end{array}$ & $\begin{array}{l}0.6 \\
86\end{array}$ & $\begin{array}{l}- \\
2.5 \\
92\end{array}$ & 0.01 & $\begin{array}{l}- \\
3.12 \\
3\end{array}$ \\
\hline $\begin{array}{l}\text { COPSOQ_TARSAS } \\
\text { _TOKE }\end{array}$ & $\sim$ & $\begin{array}{l}\text { INNOVAC } \\
\text { IO }\end{array}$ & & $\begin{array}{l}- \\
0.1 \\
53\end{array}$ & $\begin{array}{l}0.5 \\
39\end{array}$ & $\begin{array}{l}- \\
0.2 \\
83\end{array}$ & $\begin{array}{l}0.77 \\
7\end{array}$ & -1.21 \\
\hline
\end{tabular}

